総説 第 52 回（社）日本口腔外科学会総会

シンポジウム「ドライマウス 基礎から臨床」

\title{
ドライマウスの分類と診断
}

\author{
中村誠司
}

\section{Classification and diagnosis of dry mouth}

\begin{abstract}
NAKAMURA Seiji
Abstract: Evaluation of patients complaining of dry mouth symptoms is difficult because it is a common complaint with a variety of causes including Sjögren's syndrome and several possible means of assessment. Classification and diagnostic criteria of dry mouth have not been established yet, and an establishment of those is thus strongly requested. In this review, "Classification of xerostomia (dry mouth)" proposed by The Committee for Terms and Classifications, The Japanese Association for Oral Mucosal Membrane was introduced and its course and issues were also explained. Furthermore, various approaches to develop novel clinical and laboratory tests, which are useful in the differential diagnosis of dry mouth, were introduces and those future aspects were described.
\end{abstract}

Key words: dry mouth (ドライマウス), xerostomia（口腔乾燥症）, Sjögren’s syndrome（シェーグレン症候群）， classification (分類), diagnosis (診断)

は じめに

ドライマウス（口腔乾燥症）そのものは昔から知られて いた病態であるが，それ自体は生死に関わる重篤なもので はないと判断されていたことや，その診断や治療が困難で あることなどから, 積極的に取り上げられることはほとん どなかった。しかしながら最近は, 口腔に対する意識の向 上, 社会的ストレスの増加, 使用中薬剤の増加, 社会の高 齢化, 咀嚼習慣の変化などのさまざまな要因が関わってド ライマウスを訴える患者が増加し, 社会的な関心も高まっ てきた.

ドライマウスとは本来は口腔の乾燥症状を表す「症状名」 であるが，このような社会的背景もあり，最近では慣用的 に口腔の乾燥症状を示す種々の疾患を含んだ広義の「疾患 名」として用いられている. ドライマウスを生じる代表的 疾患はシェーグレン症候群であるが, それ以外にも成り立 ちが異なる種々の疾患が含まれている。むしろ, 㐘科を受 診される患者さんの場合は, シェーグレン症候群以外の原

九州大学大学院茵学研究院口腔顎顔面病態学講座顎顔面腫瘍 制御学分野

Section of Oral and Maxillofacial Oncology Division of Maxillofacial Diagnostic and Surgical Sciences Faculty of Dental Science Kyushu University
因による患者の方が多いようである.しかしながら，シェ ーグレン症候群以外のドライマウスの分類と診断方法には 統一されたものがないのが現状である. 今では有効な治療 薬が開発され, さまざまな対応方法も確立されてきている ので, ドライマウスの分類と診断を的確に行うことは極め て重要である.さらに, 学術的研究などを同一疾患群に対 して的確に行うためにも, 分類と診断方法の確立が求めら れている.

このような現状を踏まえ, 私が委員長を務める日本口腔 粘膜学会用語・分類検討委員会ではかねてよりドライマウ スの分類案を検討してきたが，2007 年 7 月 5 日の第 17 回 日本口腔粘膜学会総会でその原案を示した. 次いで, 2007 年 9 月 29 日の第 52 回 (社) 日本口腔外科学会総会のシン ポジウム「ドライマウス 〜基礎から臨床〜」では，その 原案を示して学会会員からの意見を聞くとともに討論を行 い, その結果をもとに日本口腔粘膜学会用語 - 分類検討委 員会では分類案の改訂を行った. 2008 年 9 月 19 日の第 18 回日本口腔粘膜学会総会のワークショップ「口腔乾燥症 （ドライマウス）の分類」ではその最終案を示し, 今後は 実用試行を打願いすることとなった，本総説では，現在ま での日本口腔粘膜学会用語・分類検討委員会によるドライ マウスの分類案の経緯を概説するとともに, 分類と診断方 法の現状および今後の課題や展望について述べる。 
表1 日本口腔粘膜学会用語 - 分類検討委員会による口腔 乾燥症（ドライマウス）の分類案（原案）

(第17回日本口腔粘膜学会総会で提示)

（1）全身性疾患あるいは代謝性のもの

1 ）全身性口腔乾燥症

（2）神経性・薬物性のもの

1) 神経性口腔乾燥症

2 ) 薬物性口腔乾燥症

（3）唾液腺自体の機能障害によるもの
1) シェーグレン症候群
2 ）放射線性口腔乾燥症
3 ）加齢性口腔乾燥症
4 ) 移植片対宿主病 (GVHD)
5 ）サルコイドーシス
6 ) 後天性免疫不全症候群 (AIDS)
7 ）悪性リンパ腫
8 ）特発性口腔乾燥症

注）心因性の場合は蒾科心身症と診断し，口腔乾燥症には 含めないこととする.

\section{ドライマウスの分類}

ドライマウスの原因と学術的分類はいくつか報告されて はいるが 1 ～13)，本邦では未だに確立されておらず，統一 された分類はない.

ドライマウスを原因別に分類すると，1）全身性あるいは 代謝性のもの，2）神経性・薬物性のもの，3）唾液腺自体 の機能障害によるものの 3 つに大別することができる ${ }^{10,13)}$. 日本口腔粘膜学会用語 ·分類検討委員会では, この分類方 法を基本として 2007 年 7 月 5 日の第 17 回日本口腔粘膜学 会総会で示した原案（表 1）を作成した. 全身性または代 謝性のものとしては, 糖尿病, 腎障害, 貧血などが主な原 因であるが, 口呼吸, 過呼吸, 開口, 䀧食嬹下障害などに伴 う局所的な水分蒸発によるものも含まれる. 神経性・薬物 性のものとしては, うつ病, ストレスなどの疾患や抗不安 薬, 抗うつ凨, 降圧剤などの薬剤によるものが多く, 中枢 性打よび顔面神経上唾液核などの唾液分泌神経系の抑制が 原因とされている. 唾液腺自体の機能障害によるものとし ては, シェーグレン症候群が代表的であるが, 放射線治療 や老人性変化による唾液腺障害も臨床的には重要である. なお，口腔乾燥の訴えがあるものの，他覚的口腔乾燥症状 がなく, 唾液分泌量の減少を伴わない心因性の場合は歯科 心身症と診断し, この原案には含めないこととした。

この原案を 2007 年 9 月 29 日の第 52 回（社）日本口腔 外科学会総会のシンポジウム「ドライマウス 〜基礎から 臨床〜」で示したところ，1）口腔乾燥を訴えて来院する
表2 第17回日本口腔粘膜学会総会で提示後に日本口腔粘 膜学会用語・分類検討委員会で検討した対案

1. 唾液分泌減少によるもの

（1）全身性疾患あるいは代謝性のもの

1）全身性口腔乾燥症

（2）神経性・薬物性のもの

1) 神経性口腔乾燥症

2 ）薬物性口腔乾燥症

（3）唾液腺自体の機能障害によるもの

1) シェーグレン症候群

2 ) 放射線性口腔乾燥症

3 ）加齢性口腔乾燥症

4 ) 移植片対宿主病 (GVHD)

5 ）サルコイドーシス

6 ) 後天性免疫不全症候群（AIDS）

7 ）悪性リンパ腫

8 ）特発性口腔乾燥症

2. 唾液分泌減少によらないもの

1 ) 蒸発性口腔乾燥症

2 ）心因性口腔乾燥症

注）心因性口腔乾燥症は㐘科心身症と診断する

心因性の患者は多いので,「心因性口腔乾燥症」としてこ の分類に加えるべきではないか，2）口呼吸などに伴う局 所的な水分蒸発によるもの, つまり「蒸発性口腔乾燥症」 が「全身性口腔乾燥症」に含まれているのは問題である, 3）診断のしやすさや分類の明確さを考えると, まず唾液 分泌量の減少の有無で 2 つ大別し, その上で小さく分類 してはどうかといった指摘を受けた.いずれの指摘も, 既 にそれまでの日本口腔粘膜学会用語・分類検討委員会で検 討したものであったが，これらの指摘を踏まえて改めて対 案を作成し，再び検討をすることとなった.

検討を行った対案は表 2 に示すものであったが，やはり 「心因性口腔乾燥症」は柬科心身症と診断すべきなのでこ の分類に含めるべきではなく，そうなると「唾液分泌減少 によらないもの」が「蒸発性口腔乾燥症」のみとなってし まうなどの意見が出た. 最終的には，「蒸発性口腔乾燥症」 を「全身性口腔乾燥症」から外して独立させ, 分類の順番 を頻度や重要度を考えて変更し，いくつかの名称を修正す ることとなり, 表 3 に示す最終案を作成した ${ }^{14)}$. なお，こ の最終案ではそれぞれの診断の定義あるいは根拠とともに 示すことにした。

2008 年 9 月 19 日の第 18 回日本口腔粘膜学会総会のワ ークショップ「ロ腔乾燥症（ドライマウス）の分類」でこ の最終案を示したところ，1）「心因性口腔乾燥症」は歯科 心身症と診断すべきであることを明記し, 分類に含める方 がいいのではないか，2）その上で，「唾液分泌減少による 
表3 日本口腔粘膜学会用語・分類検討委員会による口腔乾燥症（ドライマウス）の分類案（最終案） (第18回日本口腔粘膜学会総会のワークショップ「口腔乾燥症（ドライマウス）の分類」で提示）

(1) 唾液腺自体の機能障害によるもの

1) シェーグレン症候群

・1999年改訂の本邦の診断基準を満たすもの

2 ) 放射線性口腔乾燥症

・放射線治療あるいは被爆の既往がある

・唾液分泌量の減少あるいは唾液腺機能低下がある

・自覚的ならびに他覚的口腔乾燥症状がある

3 ）加歯性口腔乾燥症

・年齢が 80 歳以上

・唾液分泌量の減少あるいは唾液腺機能低下がある

・自覚的ならびに他覚的口腔乾燥症状がある

4 ) 移植片対宿主病 (GVHD)

・血液幹細胞あるいは臟器移植後のGVHD と診断されたもの

・唾液分泌量の減少あるいは唾液腺機能低下がある

・自覚的ならびに他覚的口腔乾燥症状がある

5 ）サルコイドーシス

・サルコイドーシスと診断されたもの

・唾液分泌量の減少あるいは唾液腺機能低下がある

・自覚的ならびに他覚的口腔乾燥症状がある

6 ) 後天性免疫不全症候群 (AIDS)

·AIDSと診断されたもの

・唾液分泌量の減少あるいは唾液腺機能低下がある

・自覚的ならびに他覚的口腔乾燥症状がある

7 ）悪性リンパ腫

・悪性リンパ腫と診断されたもの

・唾液分泌量の減少あるいは唾液腺機能低下がある

・自覚的ならびに他覚的口腔乾燥症状がある

8 ）特発性口腔乾燥症

・上記のいずれにも該当せず，原因が特定できなかったもの

・唾液分泌量の減少あるいは唾液腺機能低下がある

・自覚的ならびに他覚的口腔乾燥症状がある

（2）神経性あるいは薬物性のもの

1) 神経性口腔乾燥症

・恐怖，興奮，ストレス，抑うつなどの精神状態，脳炎，脳腫痬，脳外傷などの中枢性病変，顔面神経上唾液核や顔面 神経分泌枝の障害などの唾液分泌の神経系の障害などがある

・唾液分泌量の減少あるいは唾液腺機能低下がある

・自覚的ならびに他覚的口腔乾燥症状がある

2 ) 薬物性口腔乾燥症

・向精神薬，抗不安薬，抗うつ薬，抗コリン鎮瘥薬，制吐薬，抗ヒスタミン薬，降圧薬，利尿薬などを服用している

・唾液分泌量の減少あるいは唾液腺機能低下がある

・自覚的ならびに他覚的口腔乾燥症状がある

（3）全身性疾患あるいは代謝性のもの

1 ）全身代謝性口腔乾燥症

·熱性疾患，発汗過多，脱水症，下痢，尿崩症，糖尿病，甲状腺機能立進症，心不全，腎機能不全，貧血，過度のアル コール飲用，過度の喫煙などがある

・唾液分泌量の減少あるいは唾液腺機能低下がある

・自覚的ならびに他覚的口腔乾燥症状がある

2 ) 蒸発性口腔乾燥症

・口呼吸（副鼻腔炎や習慣性など），過呼吸，開口，摂食嚥下障害などを有し，口腔の環境変化による水分蒸発といった 局所的代謝異常がある

・唾液分泌量の減少および唾液腺機能低下がない

・自覚的ならびに他覚的口腔乾燥症状がある

注 1 ） 心因性の場合は㐘科心身症と診断し, 口腔乾燥症には含めないこととする. なお, 「心因性の場合」とは, 自覚的口腔乾燥 症状はあるが，他覚的口腔乾燥症状と唾液分泌量の減少がない場合をいう.

注 2 ）本分類で記載する「唾液分泌量の減少」は，ガムテストにて10分間で $10 \mathrm{ml}$ 以下，Saxon テストにて 2 分間で2 g以下，安 静時唾液量にて15分間で $1.5 \mathrm{ml}$ 以下の少なくともいずれかに該当するものとする．また，「唾液腺機能低下」は唾液腺シ ンチグラフィーにて機能低下を認めるものとする. 
表4 日本におけるシェーグレン症候群診断基準（1999年改訂）

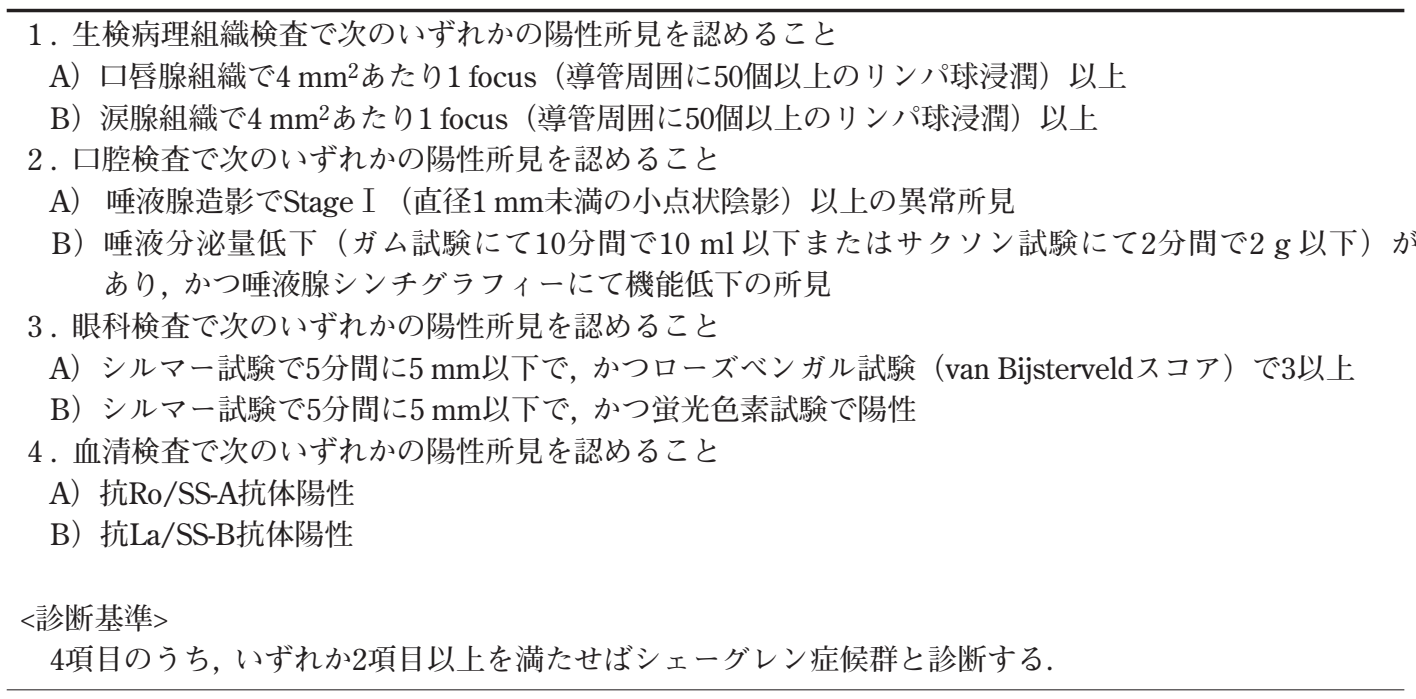

もの」と「唾液分泌減少によらないもの」に大別してはど うかという, 第 52 回 (社) 日本口腔外科学会総会の時と 同様の指摘があった。 その他, AIDS を発症していない HIV 感染状態を加えてはどうか, 加齢による口腔乾燥症は本当 にあるのか, ミクリッツ病（IgG4 関連疾患）を加えてはど うかなどの指摘もあった。 今後は多くの方々に日々の診療 でこの最終案を実用試行していただき，その上で御意見が あれば必要に応じて改訂を重ねていくことになった.

日本口腔粘膜学会用語・分類検討委員会はこれまでに 8 回開催された. 当事者としては, 数多くの議論の末によう やくここまで辿り着いたという感があるが, 今後はこの改 訂分類案を関連学会でも検討する必要があろう。場合によ つては関連学会合同の委員会を立ち上げ，可及的に早く多 くの方々のコンセンサスを得て, 本邦におけるドライマウ スの分類が確立されることを期待する.

\section{ドライマウスの検査および診断}

ドライマウスの分類が決まれば，その次には具体的な検 査あるいは診断方法およびその基準を検討する必要があろ う. 現時点で確立されている検査および診断方法は, 表 4 に示す本邦のシェーグレン症候群の診断基準 ${ }^{15)}$ のみであ るので, この診断基準を柱として䛦断していくことが基本 になろう. 図 1 に診断の流れ（フローチャート）を示すが, 今後はシェーグレン症候群以外のドライマウスを診断する 際の, 原因の精査を含めた検査および診断方法を検討して いく必要があろう.

表 3 の最終案では, 唾液腺機能の評価項目として「唾液
分泌量の減少」と「唾液腺機能低下」という2つの項目を 用いているが, これらの評価はドライマウスを分類するた めには極めて重要である. 注釈にこれらの評価項目の定義 を記しているが,「唾液分泌量の減少」は, ガムテストに て 10 分間で $10 \mathrm{ml}$ 以下, サクソンテストにて 2 分間で $2 \mathrm{~g}$ 以下, 安静時唾液量にて 15 分間で $1.5 \mathrm{ml}$ 以下の少なくと もいずれかに該当するもの，「唾液腺機能低下」は唾液腺 シンチグラフィーにて機能低下を認めるものとしている. その他の検査方法としては, シェーグレン症候群の診断基

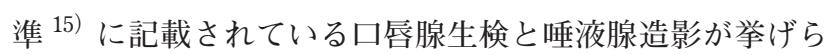
れる.ただし，ドライマウスを訴えて一般の歯科医院を受 診する患者はとても多いので, 特に唾液腺自体の機能障害 がない場合には一般の柬科医院でも対応できることが求め られており，そのためには簡便かつ正確な診察あるいは検 査方法が必要であろう。一般の柬科医院では，唾液腺シン チグラフィーと唾液腺造影を実施することは困難であるの で, 自・他覚的口腔乾燥症状の診査と唾液分泌量の測定, そして必要に応じて口唇腺生検を行うことで診断すること になろう. 表 3 の最終案に示しているように, 原因あるい は誘因の同定が可能でありさえすれば, 自・他覚的口腔乾 燥症状の診査と唾液分泌量の測定のみで診断できるものは 少なくない.これらの検査で診断が困難な場合には口腔外 科で検査および診断をすることになろう.

このように, 自・他覚的口腔乾燥症状の診査と唾液腺機 能の評価の 2 つは分類と診断に極めて重要である. 自・他 覚的な口腔乾燥症状の診査に関しては, 診査すべき項目は 十分に知られており, 問診表や visual analogue scale (VAS) を用いたり, 口腔粘膜, 歯, 歯周組織などの状態や口腔 


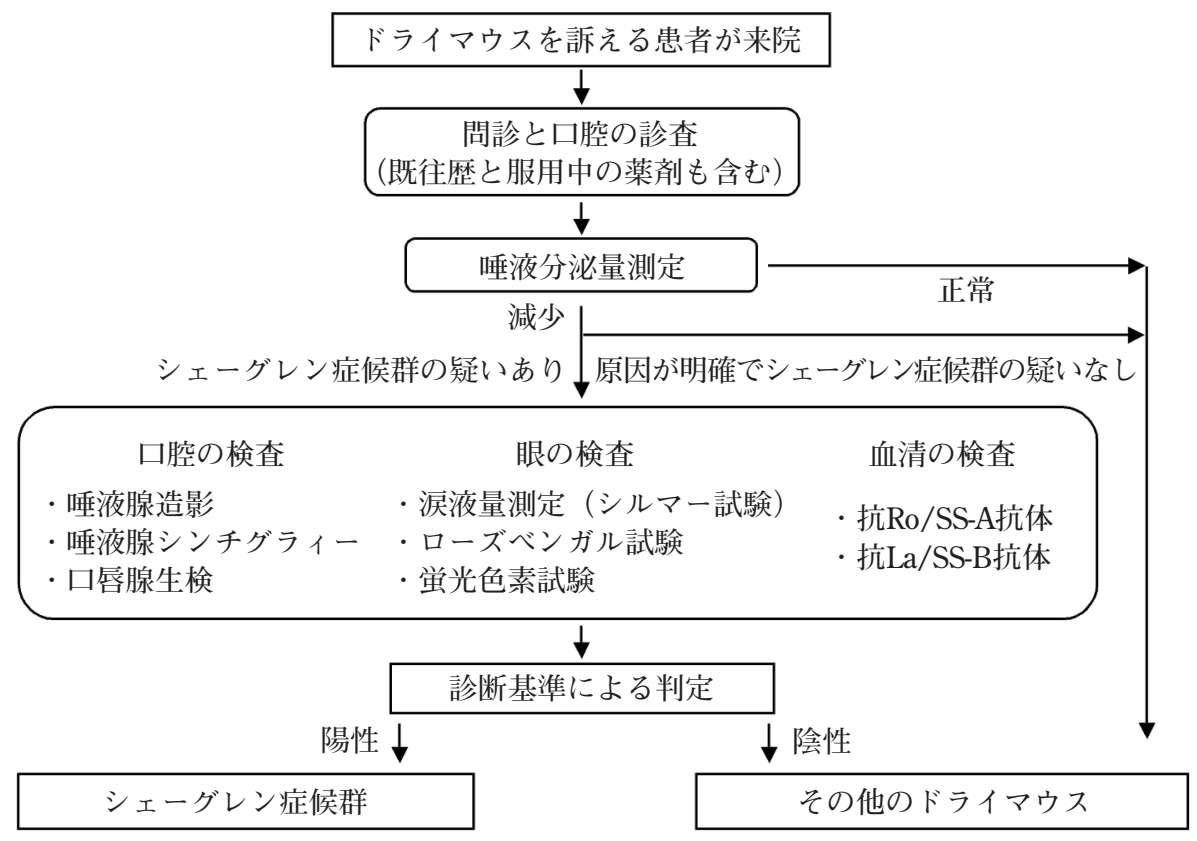

図 1 ドライマウスの診断の流れ（フローチャート）

衛生状態を診査したりすることで比較的容易に評価でき る ${ }^{10 \sim 13,16)}$. ただし，それらの症状の程度を客観的に評価 することは容易ではない. 唾液腺機能の評価方法は, 前述 のように唾液分泌量の測定と唾液腺シンチグラフィーの 2 つがあるが，唾液分泌量の測定はその簡便さもあって臨床 的に極めて重要である。その方法としては, 刺激時唾液 分泌量を調べるガムテストやサクソンテストが一般的 であるが，安静時唾液分泌量を調べる吐唾法も有用であ る $12,13,16 \sim 20)$. 特に, 神経性口腔乾燥症の場合には安静 時唾液分泌量の方が著明に減少するので, 刺激時と安静時 の両方を調べることは重要である ${ }^{13)}$. ただし, いずれの検 査も測定条件によって結果が異なることも少なくなく，あ まり正確とは言えないのが問題である，その他の唾液分泌 量の測定あるいは類似した検査として, ワッテ法による安 静時唾液分泌量の測定, 口腔水分計を用いた口腔粘膜水 分量測定, 検査紙を用いた唾液湿潤度検査, 曳糸性測定 器（NEVA-METER ${ }^{\circledR}$ ) を用いた唾液の物性検査などがあ る ${ }^{12,16,20)}$.いずれも簡便な方法であり, 短時間で評価が 可能であったり, 高齢者や障害者などでも実施可能であっ たりと, 利点もある. 今後, 一般的に認められているガム テスト, サクソンテスト, 吐唾法との関連性や整合性など を検討すれば，十分に活用できると期待できる.

唾液腺機能を評価するもう一つの方法である唾液腺シン チグラフィーは, 施行できる施設が限定されるものの, 唾 液腺機能を評価できる高感度あるいは高精度の検査として
有用である $\left.{ }^{3}, 12,16,20 ２ 2\right)$. 現時点では統一された評価方 法や基準はないが，アイソトープの唾液腺への集積とレモ ンなどによる分泌刺激時の排泄を詳細に調べることによ り，ドライマウスの分類にも活用できる可能性もあろう. シェーグレン症候群を含めた唾液腺自体の機能障害によ るドライマウスが考えられる場合には, 唾液腺の器質的変 化を調べることが重要になる.シェーグレン症候群の診 断基準には口唇腺生検と唾液腺造影が含まれており，い ずれも有用な検査である。近年, 超音波検査, CT, MRI, MR-sialography などの診断における有用性が報告されてお り ${ }^{12,16,23 \sim 25)}$, さらなる検討と実用化が望まれる.

\section{ドライマウスの検査における新たな試み}

前述のように, 今後はドライマウスの分類の確立ととも に, シェーグレン症候群以外のドライマウスについても原 因の精査を含めた検査および診断方法を検討しないといけ ない. また，多くのドライマウス患者が一般の菊科医院を 受診していることを考えると, 簡便かつ正確な新しい検査 方法の確立が求められる. そのような理想的な検査方法が 確立できれば，ドライマウスの診療はさらに一般化される であろう.

新たな検査方法の一つとして期待できるのは検体として 唾液を用いる検査である。唾液の採取は簡単であり, 何よ りも非侵襲的であり, 繰り返し採取して経過をみることも 

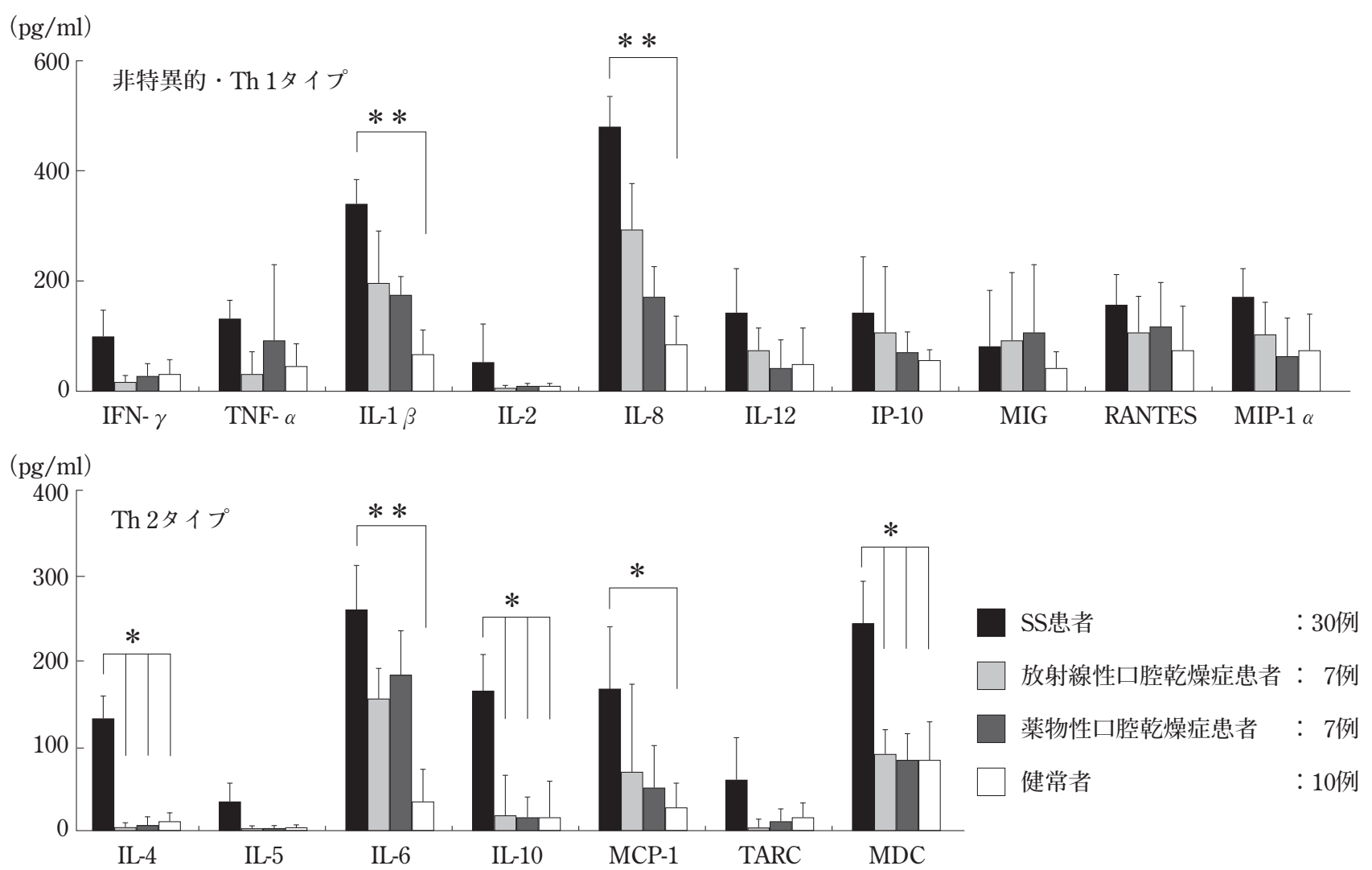

図 2 唾液中のサイトカインとケモカインの濃度（疾患別の比較）

シェーグレン症候群 (SS), 放射線性口腔乾燥症, 薬物性口腔乾燥症, それぞれの患者と健常者から採取し た唾液中のサイトカインとケモカインの濃度を示している. SS 患者では，IL-1 $\beta ， I L-8 ， I L-4 ， I L-6 ， I L-10$, MCP-1，MDC が健常者よりも有意に高值であり，IL-4，IL-10，MDC は他の口腔乾燥症患者と比較しても有意 に高かった (Student's $t$ 検定 : * $P<0.05$ ，** $P<0.01$ )。これらの結果は, SS 患者の唾液腺内では非特異 的, Th1 タイプ, Th2 タイプの多くのサイトカインやケモカインの mRNAが検出されるという我々の過去の 報告と一致している.

可能であるという利点がある. 第 52 回（社）日本口腔外 科学会総会のシンポジウム「ドライマウス 〜基礎から臨 床〜」でも解説したが, 私の教室ではこれまでのシェーグ レン症候群の病態に関する研究成果 ${ }^{26}$ ～30) を踏まえ，唾 液中のサイトカインやケモカインなどの液性分子を測定し ている(結果は投稿準備中)。また，炎の際にはフローサイ トメトリーや酵素抗体法（ELISA）といった高感度かつ正 確な測定方法を用いて打り, $1 \mathrm{ml}$ 未満の少量の喠液を用い て一度に多くの分子を測定できるように工夫している. 図 2 にはシェーグレン症候群, 放射線性口腔乾燥症, 薬物性口 腔乾燥症，穴れぞれの患者と健常者から採取した喠液にお ける結果を示している。 シェーグレン症候群患者の唾液腺 では, 浸潤する T細胞はサイトカイン，唾液腺導管上皮は ケモカインなどをそれぞれ産生しているが，これらの液性 分子は唾液中でも検出できることが示された．また，一部
の分子は放射線性口腔乾燥症と薬物性口腔乾燥症の患者の 唾液中にも検出されるものの, いくつかの分子を組み合わ せればシェーグレン症候群を鑑別することも可能であるこ とも示唆された. 図 3 にはシェーグレン症候群患者に打け る唾液腺病変の重症度との関連を示している. シェーグレ ン症候群患者の唾液腺では, 病変の重症度と関連して産生 されるサイトカインやケモカインが変化することが判って いるが，穴の変化は唾液中でもみられることが示された。 このように, 唾液中に検出されるサイトカインやケモカイ ンといった液性分子は唾液腺の病態を十分に反映し, 診断 や病態の把握が可能であることが示唆された。 現在, 唾液 に含まれるそれ以外の分子も測定しており，唾液の成分に よりドライマウスの分類が可能なのか, もし可能であれば どのような分子を測定すれば良いかを詳細に検討中であ る. 


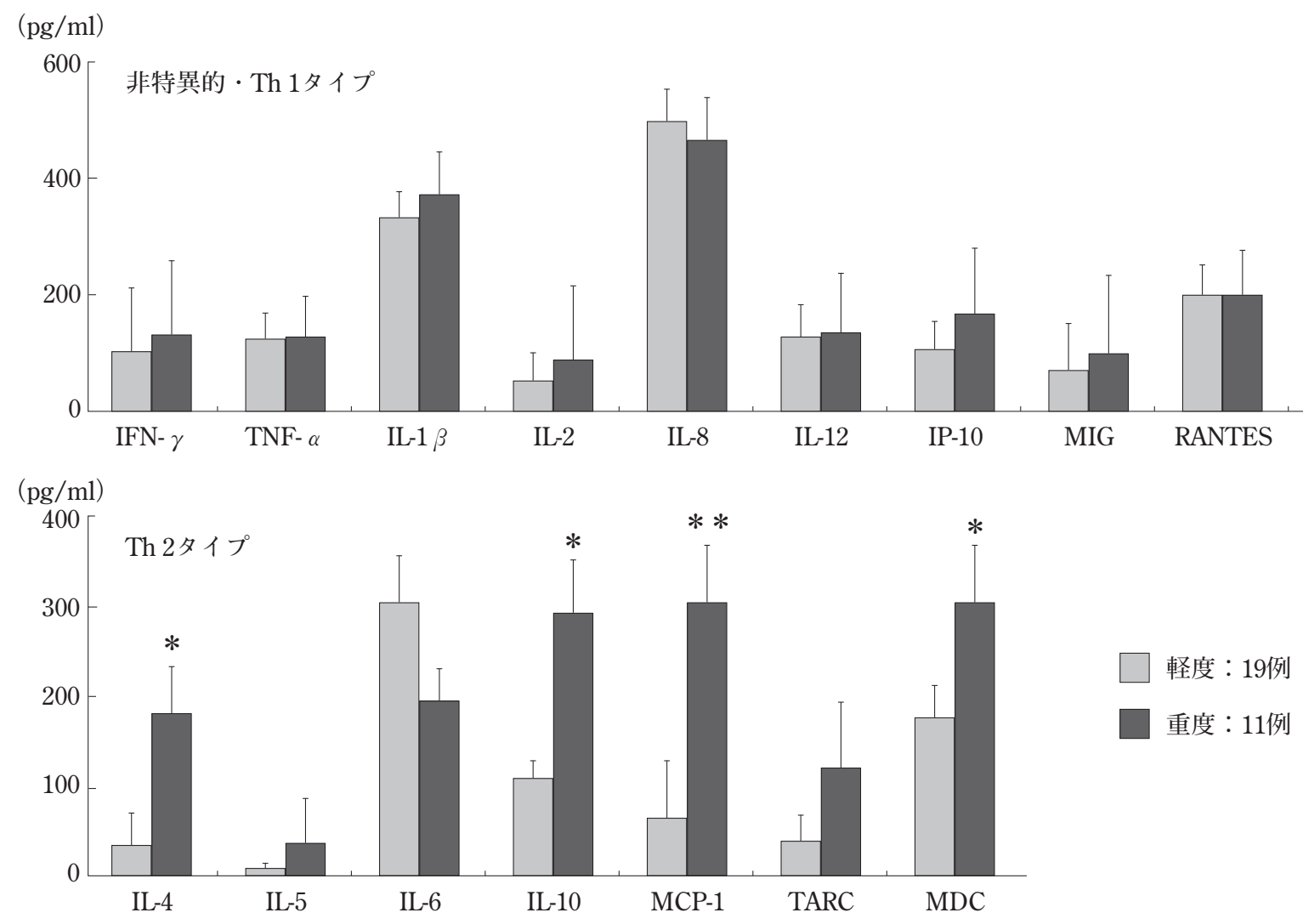

図 3 唾液中のサイトカインとケモカインの濃度（シェーグレン症候群の重症度別の比較）

シェーグレン症候群（SS）患者を唾液腺内のリンパ球浸潤程度により重度と軽度の 2 群に分け, 唾液中の サイトカインとケモカインの濃度を比較したところ, 重度の SS 患者では, 軽度の SS 患者よりも IL-4, IL-10, MCP-1, MDC が有意に高值であった (Student's $t$ 検定：*P<0.05，**P<0.01).これらの結果は，非特 異的ならびに Th1 タイプのサイトカインやケモカインの mRNA は重症度に関係なくすべての SS 患者の唾液 腺内で検出され，一方，Th2 タイプのサイトカインやケモカインの mRNA は重度の SS 患者の唾液腺内では 検出されるが, 軽度では検出されないという我々の過去の報告と一致している。

\section{今後の課題や展望}

ドライマウスは新しい診療分野ということもあって，明 確な EBMに乏しいところも少なくなく，今後はさらに EBM を積み重ねていく必要があろう。私の教室の研究は, ドライマウスの新たな分類と診断方法を確立しようとする $1 つ の$ 例に過ぎない. 現在, 多くの施設が積極的にドライ マウスの診療に取り組むとともに, 精力的に基礎的あるい は臨床的研究を行っている. 簡便かつ正確な分類と診断方 法が確立されれば, 歯科医あるいは口腔外科医が携わる疾 患としてさらに認識が高まり, 新たな診療分野として確立 されるであろうと期待している.

謝辞

ドライマウスの分類案作成に多大な御尽力をいただきまし
た日本口腔粘膜学会用語 ·分類検討委員会の構成委員である 伊東大典, 川辺良一, 草間幹夫, 神部芳則, 南雲正男, 藤林孝 司, 前田初彦, 又賀 泉, 山根源之（敬称略, 五十音順）の全 員に深謝いたします。

\section{引用 文 献}

1）奥田 稔：唾液腺機能検査法とその臨床. 耳喉 32: 913-925 1960 .

2) 神田 敬, 北村 武：口腔乾燥症（Xerostomiasis） の分類. 耳喉 44: 51-57 1972.

3) Schall, G.L., Larson, S.M., et al.: Quantification of parotid gland uptake of pertechnetate using a gamma scintillation camera and a "region-of-interest" system. Am J Roentgenol Radium Ther Nucl Med 115: 689-697 1972.

4) Bahn, S.L. and Conn, W.H.: Drug-related dental destruction. Oral Surg 33: 49-54 1972. 
5) Spielman, A., Ben-Aryeh, H., et al.: XerostomiaDiagnosis and treatment. Oral Surg 51: 144-147 1981.

6) Ettinger, R.L.: Xerostomia-a complication of ageing. Aust Dent J 26: 365-371 1981.

7) 水野吉広, 福田 博, 他: 唾液腺疾患の臨床的研究 第 1 報 12 年間の臨床統計. 日口外誌 28: 903-916 1982.

8) Navazesh, M. and Ship, I.I.: Xerostomia: Diagnosis and treatment. Am J Otolaryngol 4: 283-292 1983.

9）山根源之：口腔乾燥症の診断と治療. 歯科ジャーナ ル 28: 111-117 1988 .

10）藤林孝司：口腔乾燥症. 南雲正男編; 口内炎, 口腔 乾燥症の正しい口腔ケア. 医薬ジャーナル社, 東京, 2001, 8-12 頁.

11）稲永清敏，中村誠司，他：ドライマウスの原因とそ の診断. 斎藤一郎, 篠原正德, 他編 ; ドライマウス の臨床, 医蒾薬出版, 東京, 2007, 1-61 頁.

12）安細敏弘, 柿木保明, 他: 口腔乾燥症の検査と診断. 安細敏弘, 柿木保明編; 今日からはじめる! 口腔 乾燥症の治療 この主訴にこのアプローチ. 医柬薬 出版, 東京, 2008, 11-68 頁.

13）中村誠司: 口腔乾燥症. 尾崎登喜雄編; 口腔内科学. 飛鳥出版室, 高知, 2008, 403-407 頁.

14）日本口腔粘膜学会の口腔乾燥症（ドライマウス）の 分類案. 日腔粘膜誌 14: 86-88 2008.

15） Fujibayashi, T., Sugai, S., et al.: Revised Japanese criteria for Sjögren's syndrome (1999): availability and validity. Mod Rheumatol 14: 425-434 2004.

16）中川洋一, 山近重生, 他：ドライマウスの診断に必 要な検査. 斎藤一郎, 篠原正德, 他編; ドライマウ スの臨床, 医㐘薬出版, 東京, 2007, 61-102 頁.

17）大藤 真：昭和 52 年度研究報告総括. 厚生省特定 疾患シェーグレン病調査研究班, 昭和 52 年度研究 業績, 1978, 3-6 頁.

18) Kohler, P.F., Winter, M.E., et al.: A quantitative test for xerostomia: The Saxon test, an oral equivalent of the Schirmer test. Arthritis Rheum 28: 1128-1132 1985.

19) Vitali, C., Bombardieri, S., et al.: Classification criteria for Sjögren's syndrome: A revised version of the European criteria proposed by the AmericanEuropean Consensus Group. Ann Rheum Dis 61: 554-
5582002.

20）柿木保明, 中村誠司, 他：唾液検査の実際と診断の ポイント. 特集 ; 口腔乾燥症の臨床一診断と治療 のガイドライン一. 菌界展望 103: 47-52 2004.

21）東 与光, 古川恵司, 他 : 唾液腺の ${ }^{99 \mathrm{~m}} \mathrm{Tc}$ 連続シン チグラフィの臨床的意義. 日口科誌 31: 46-53 1982.

22）又賀 泉：慢性腎不全透析療法中患者にみられる口 腔乾燥に対する臨床的研究. 日口外誌 29: 1901-1920 1983.

23) Shimizu, M., Okamura, K., et al.: Sonographic diagnosis criteria for screening Sjögren's syndrome. Oral Surg Oral Med Oral Pathol Oral Radiol Endod 102: 85-93 2006.

24) Izumi, M., Eguchi, K., et al.: MR imaging of the parotid gland in Sjögren's syndrome: a proposal for new diagnostic criteria. Am J Roentgenol 166: 148314871996.

25) Ohbayashi, N., Yamada, I., et al.: Sjö gren's syndrome: comparison of assessments with MR sialography and conventional sialography. Radiology 209: 683-688 1998.

26) Ohyama, Y., Nakamura, S., et al.: Cytokine messenger RNA expression in the labial salivary glands of patients with Sjögren's syndrome. Arthritis Rheum 39: 1376-1384 1996.

27) Nakamura, S., Ohyama, Y., et al.: Cytokine expression in the salivary glands of Sjögren's patients according to the tissue infiltrate and lymphoepithelial lesions (Letters). Arthritis Rheum 40: 989-990 1997.

28) Nakamura, S., Hiroki-Ikebe, A., et al.: An association between salivary gland disease and serological abnormalities in Sjögren's syndrome. J Oral Pathol Med 26: 426-430 1997.

29) Ohyama, Y., Nakamura, S., et al.: Accumulation of human T lymphotrophic virus type I (HTLV-I) infected $\mathrm{T}$ cells in the salivary glands of patients with HTLV-I-associated Sjö gren's syndrome. Arthritis Rheum 41: 1972-1978 1998.

30) Tsunawaki, S., Nakamura, S., et al.: Possible function of salivary gland epithelial cells as nonprofessional antigen-presenting cells in the development of Sjögren's syndrome. J Rheumatol 29: 1884-1896 2002. 